\title{
IRON SOURCES FOR CITRUS ROOTSTOCK DEVELOPMENT GROWN ON PINE BARK/VERMICULITE MIXED SUBSTRATE
}

\author{
Rhuanito Soranz Ferrarezi ${ }^{1 *}$; Ondino Cleante Bataglia苂 Pedro Roberto Furlani ${ }^{1}$; Eliana \\ Aparecida Schammass ${ }^{2}$ \\ ${ }^{1}$ Instituto Agronômico - Centro de Pesquisa e Desenvolvimento de Solos e Recursos Ambientais, C.P. 28 - 13001-970 - \\ Campinas, SP - Brasil. \\ Instituto de Zootecnia - Centro de Pesquisa e Desenvolvimento de Genética e Reprodução Animal, C.P. 60 - \\ 13460-000 - Nova Odessa, SP - Brasil. \\ *Corresponding author <rhuanito@rhuanito.com.br>
}

\begin{abstract}
For high technology seedling production systems, nutrition plays an important role, mainly the fertigation with iron chelates to prevent its deficiency. This study had the goal of searching for alternative iron sources with the same nutrient efficiency but lower cost in relation to nutrient solution total cost. An experiment was carried out in $56 \mathrm{~cm}^{3}$-conic-containers tilled with a pine bark/ vermiculite mixed substrate using Fe-DTPA, Fe-EDDHA, Fe-EDDHMA, Fe-EDTA, Fe-HEDTA, FeCl ${ }_{3}$, $\mathrm{FeSO}_{4}, \mathrm{FeSO}_{4}+$ citric acid plus a control, and the rootstocks Swingle, Rangpur, Trifoliata and Cleopatra, in a randomized complete block design, with four replicates. Seedlings were evaluated for height, relative chlorophyll index, total and soluble iron leaf concentrations. Cleopatra was the only rootstock observed without visual iron chlorosis symptoms. There was a low relative chlorophyll index for Rangpur, Swingle and Trifoliata rootstocks in the control plots, in agreement with the observed symptoms. High total iron concentrations were found in the control and Fe-EDTA plots, whereas soluble iron represented only a low percent of the total iron. The economical analysis showed the following cost values of iron sources in relation to the nutrient solution total costs: Fe-HEDTA $(37.25 \%)>\mathrm{FeCl}_{3}(4.61 \%)>$ Fe-EDDHMA (4.53\%) $>$ Fe-EDDHA (3.35\%) $>$ Fe-DTPA (2.91\%) $>$ FeEDTA $(1.08 \%)>\mathrm{FeSO}_{4}+$ citric acid $(0.78 \%)>\mathrm{FeSO}_{4}$ (0.25\%). However, only plants from Fe-EDDHA and Fe-EDDHMA treatments did not present any deficiency visual symptoms. The relative cost of FeEDDHA application is low, its efficiency in maintaining iron available in solution resulted in high plant heights, making it recommendable for citric rootstock production in nurseries.
\end{abstract}

Key words: seedling production, chelates, fertigation, economical analysis

\section{FONTES DE FERRO PARAO DESENVOLVIMENTO DE PORTA-ENXERTOS CÍTRICOS PRODUZIDOS EM SUBSTRATO DE CASCADE PINUS E VERMICULITA}

\begin{abstract}
RESUMO: No sistema altamente especializado de produção de mudas, a nutrição exerce papel importante, principalmente a fertirrigação com quelatos de ferro para evitar sua deficiência. O objetivo deste estudo foi buscar fontes alternativas de ferro que propiciem a mesma eficiência de aproveitamento e menor custo em relação ao total da solução nutritiva. Avaliaram-se os porta-enxertos Swingle, Cravo, Trifoliata e Cleópatra, em tubetes com substrato de casca de pinus/vermiculita, e as fontes de ferro Fe-DTPA, FeEDDHA, Fe-EDDHMA, Fe-EDTA, Fe-HEDTA, $\mathrm{FeCl}_{3}, \mathrm{FeSO}_{4}, \mathrm{FeSO}_{4}$ +ácido cítrico e Testemunha. Utilizouse o delineamento em blocos casualisados, com quatro repetições. Foram analisados altura das plantas, índice relativo de clorofila, teor na folha de Fe total e solúvel. Cleópatra foi o único porta-enxerto que não apresentou sintoma visual de deficiência de ferro. Houve baixo índice relativo de clorofila na Testemunha dos porta-enxertos Cravo, Swingle e Trifoliata, comprovando os sintomas visuais observados. Verificouse alta concentração de Fe total e menor \% de ferro solúvel da Testemunha e do Fe-EDTA. Na análise econômica, as fontes de ferro foram classificadas em relação ao custo total da solução nutritiva: Fe$\operatorname{HEDTA}(37,25 \%)>\mathrm{FeCl}_{3}(4,61 \%)>\mathrm{Fe}-\operatorname{EDDHMA}(4,53 \%)>\mathrm{Fe}-\operatorname{EDDHA}(3,35 \%)>\mathrm{Fe}-\mathrm{DTPA}(2,91 \%)>$ Fe-EDTA $(1,08 \%)>\mathrm{FeSO}_{4}$ +ácido cítrico $(0,78 \%)>\mathrm{FeSO}_{4}(0,25 \%)$. No entanto, somente as plantas dos tratamentos Fe-EDDHA e Fe-EDDHMA não apresentaram sintomas visuais de deficiência. Fe-EDDHA propiciou melhor desempenho sob o aspecto nutricional e na altura das plantas do que Fe-EDDHMA, sendo recomendado para a produção de mudas cítricas nos viveiros.

Palavras-chave: produção de mudas, quelatos, fertirrigação, análise econômica
\end{abstract}




\section{INTRODUCTION}

Brazil holds the position of world's largest orange producer, with a cultivated area of 820 thousand hectares, yielding 447.81 million boxes of $40.8 \mathrm{Kg}$, what represents $49 \%$ of the total Brazilian fruit production. The citrus industry moves more than US\$ 5 billion per year in the productive chain, with investments of US\$ 2.2 billion in both new and in-production orchards (Ferrarezi, 2006). To keep high production levels and to assure the position of market leaders, the industries make large investments in equipment, citrus technology, logistics and marketing.

The emergence and aggravation of diseases and pests requires quality scion production under protected nurseries, according to the Rules for Certified Citrus Seedling Production in the State of São Paulo, Brazil. Nowadays, there are 543 nurseries producing more than 12 million citrus seedlings annually in the São Paulo State. More than US\$ 50 million were invested in technology in the last 5 years for nursery seedling production and orchard renovation and planting (Ferrarezi, 2006).

Protected citrus seedling production requires adequate nutrition and the substrate requires additional amendment, mainly regular applications of iron to avoid Fe-deficient seedlings. Iron is frequently applied during fertigation through dripping systems, but its availability to the plants would depend on the substrate used and might vary substantially (Gárate \& Lucena, 1991).

Iron deficiency alters the photosynthetic apparatus structure and function of superior plants, drastically reducing the quantity of green pigments on deficient leaves and relatively enriching them with yellow pigments, due to the increase in some carotenoids of chloroplasts (Yunta et al., 2003a). As a consequence, Fe-deficiency symptoms occur first in young leaves, being characterized by yellow leaves with green central and side nervures (Römheld, 2001). This affects the mineral nutrient content, the production and quality of fruit trees (Bañuls et al., 2003).

A metal-chelate is the result of a special complexing reaction in which the formed complex shows multiple connections in a structure around a metallic ion (Albano \& Miller, 1995). Chelates maintain metals soluble in adverse chemical environments where metal ions might precipitate in the form of oxides or hydroxides. Thus, the use of synthetic iron chelates is the most usual and effective way to prevent Fe-deficiency in plants.

When iron-chelates are added to a substrate, large amounts of soluble iron are maintained in solution without being displaced by other cations or re- tained by the substrate surface negative charges (Lucena, 2003). According to García-Marco et al. (2006), Fe-efficient plants have developed two different strategies to assimilate iron when its availability is low. In Strategy I plants (dicots and nongrass monocots), plant roots are able to increase a plasma membrane-bound $\mathrm{Fe}^{3+}$ reductase (FC-R), that directly reduces extracellular $\mathrm{Fe}^{3+}$ from the chelates to $\mathrm{Fe}^{2+}$ (Bienfait, 1985). The $\mathrm{Fe}^{2+}$ can be transported into the roots by a plasma membrane transporter (transporter T) (García-Marco et al., 2006). The greater difference compared to other non-chelated Fe-compounds, is that the chelating agent is transported back to the substrate solid phase to chelatize more irons. When the chelate returns to the solution it can chelatize large amounts of iron in a short period of time (Pérez-Sanz \& Lucena, 1995).

Nowadays, chelating agents used to obtain chelated micronutrients are available as different molecules and isomers, all of them as polyamine carboxylic acids used to obtain chelated micronutrients: DTPA (Diethylene triaminepentaacetic acid) (5 in Figure 1), EDDHA (Ethylene diamine di-[o-hydroxyphenylacetic] acid) (1, 2 and $\mathbf{3}$ in Figure 1), EDDHMA (Ethylene diamine di- [o-hydroxy-methylphenyl] acetic acid) (4 in Figure 1), EDTA (Ethylene diaminetetraacetic acid) (6 in Figure 1) and HEDTA (Hydroxyethylene

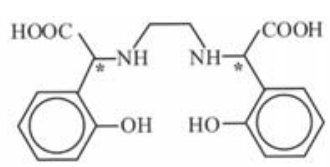

(1) $o, o-\mathrm{EDDHA}$
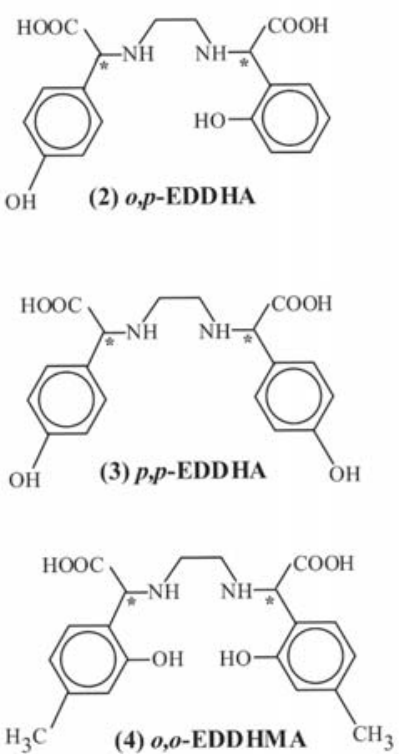

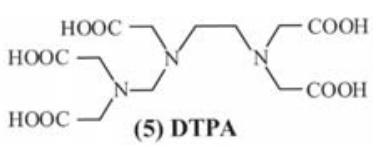

(5) DTPA

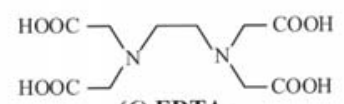

(6) EDTA

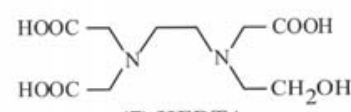

(7) HEDTA
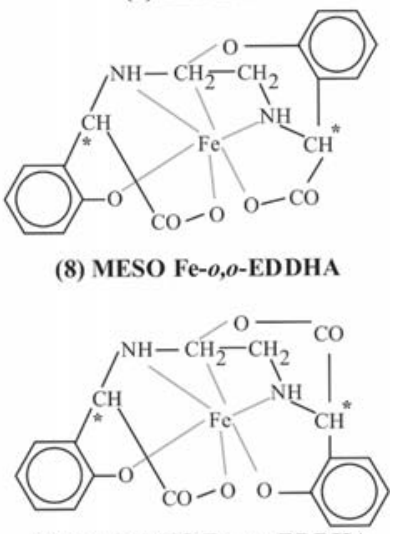

(9) RACEMIC Fe-o, o-EDDHA
(8) MESO Fe-o,o-EDDHA

Figure 1 - Chelating agents used to prevent and correct iron deficiency. *Chiral carbons 
diaminetriacetic acid) (7 in Figure 1) (Yunta et al., 2003a). These chelating agents usually have high $\mathrm{Fe}^{3+}$ specificity and form highly stable metallic chelates. In absence of competitor ions Fe-EDTA stays unaffected up to $\mathrm{pH}$ 6; Fe-EDDHA up to $\mathrm{pH}$ 9; FeEDDHMA up to pH 11; and Fe-DTPA up to 7.5 (Bermúdez et al., 2002). The Fe-HEDTA is moderately stable under acid and neutral conditions, between $\mathrm{pH}$ 4.8 and 6.7. Above $\mathrm{pH} 7.5$ this chelate presents very low stability (Norvell, 1972).

During the industrial synthesis of EDDHA, a mixture of three isomeric products is produced, depending on the position of the hydroxyl and phenyl groups in the aromatic ring (Bermúdez et al., 2002). These isomers are $o, o$ - EDDHA, $o, p$-EDDHA and $p, p$ EDDHA (1, 2 and 3, respectively, in Figure 1), which show different abilities to chelate metallic ions, the $0,0-$ EDDHA being the most efficient chelating agent, because of its high stability metallic complexes (Yunta et al., 2003b).

In the commercial synthesis, $\mathrm{Fe}-0, o$-EDDHA (1 in Figure 1) and Fe-o,o-EDDHMA (4 in Figure 1), are obtained as a mix of two geometric isomers at a $50 \%$ rate each: a meso (8 in Figure 1 ) and a racemic (9 in Figure 1) form (Bermúdez et al., 2002). The $\mathrm{Fe}-0,0$-EDDHA racemic form is more stable than a meso isomer, while the opposite happens with the FeEDDHMA isomers: the meso form is more stable than the racemic one (Ahrland et al., 1990). However, more stable chelates, like Fe-EDDHA and FeEDDHMA, are more expensive, justifying a search for cheaper iron sources in substrate at lower $\mathrm{pH}$. As alternatives, other iron chelates, like Fe-DTPA, Fe-EDTA and Fe-HEDTA might be used. However, their efficiency in correcting iron chlorosis is smaller when compared to other chelates (Lucena et al., 1992; Sánchez-Andreu et al., 1991). In the same way, inorganic fertilizers could be used, like ferrous sulfate $\left(\mathrm{FeSO}_{4} \cdot \mathrm{H}_{2} \mathrm{O}\right.$ or $\left.\mathrm{FeSO}_{4} \cdot 7 \mathrm{H}_{2} \mathrm{O}\right)$ and ferric chloride $\left(\mathrm{FeCl}_{3} \cdot 6 \mathrm{H}_{2} \mathrm{O}\right)$ (Natt, 1992). On the other hand, iron can easily precipitate in nutrient solution due to $\mathrm{Fe}$ displacement from the chelate by other elements, and subsequent precipitation of iron hydroxide, turning $\mathrm{Fe}$ unavailable to plants, inducing chlorosis and blocking the drip system. Therefore, complexing substances like citric acid, humic acids and derivates have also been tested to minimize this problem (Álvarez-Fernández et al., 1996).

The objectives of the present work were to evaluate citrus rootstock efficiencies in the utilization of several iron sources, to estimate the costs of these products in nutrient solution and to evaluate their effects on plant height, leaf soluble and total iron concentration and relative chlorophyll content.

\section{MATERIAL AND METHODS}

The experiment was conducted in greenhouse, at Campinas, SP, Brazil $\left(22^{\circ} 54^{\prime} \mathrm{S}, 47^{\circ} 05^{\prime} \mathrm{W}\right.$, and 674 $\mathrm{m}$ altitude). The temperature and relative humidity were registered by a thermo-hygrograph (Elcometer 6700 Electronic $^{\circledR}$ ) during the experimental period. The average of the maximum temperature was $34.4^{\circ} \mathrm{C}$ and the minimum $17.2^{\circ} \mathrm{C}$. The average of the maximum relative humidity was $83.6 \%$ and the minimum $24.6 \%$.

The treatments consisted of five iron chelates (Fe-DTPA, Fe-EDDHA, Fe-EDDHMA, Fe-EDTA and Fe-HEDTA), three salts $\left(\mathrm{FeCl}_{3}, \mathrm{FeSO}_{4}\right.$ e $\mathrm{FeSO}_{4}+$ citric acid) and an iron-free control; and four citrus rootstocks (Rangpur lime Limeira [Citrus limonia Osbeck], Cleopatra mandarin [Citrus reshni hort. ex Tanaka], Swingle citrumelo [Citrus paradisi Macfad. cv. Duncan x Poncirus trifoliata (L.) Raf.], Poncirus trifoliata Limeira [Poncirus trifoliata (L.) Raf.]. The iron sources chosen are available in the market, as commercial chelates and laboratory high pure grade salts. The products were previously analyzed by atomic absorption spectrometry to determine their iron concentration (Table 1).

Citrus rootstock seedlings were grown (from August $22^{\text {nd }}, 2004$ to February $\left.2^{\text {nd }}, 2005\right)$ in $56 \mathrm{~cm}^{3}$ conic containers (cone-tainers), open at the bottom to allow drainage. A commercial pp plan tray, with dimensions $695 \times 420 \times 30 \mathrm{~mm}$, for cone-tainers with 228 cells $(19 \times 12$ cells), was divided into four parts for sowing the rootstocks. Fifty-six plants of each rootstock were sown and, after one month, the best 40 plants of each rootstock were selected, totalling 160 plants. Rootstocks were separated by lines, resulting in 18 useful plants of each rootstock for biometric and chemical analyses. The positions of the trays in the greenhouse were weekly changed to minimize the experimental errors.

The used commercial growth medium was composed by ground pine bark and vermiculite. This substrate was characterized according to the Dutch method (1:1.5 substrate:water), adapted from Sonneveld \& Elderen (1994). Results were as follows: $\mathrm{pH}=5.9$, electric conductivity $(\mathrm{EC})=0.1 \mathrm{dS}^{-1}$ and (in $\left.\mathrm{mg} \mathrm{L}^{-1}\right)$ total $-\mathrm{N}=6.6\left(\mathrm{NO}_{3}^{-}-\mathrm{N}=0.8\right.$ and $\left.\mathrm{NH}_{4}^{-}-\mathrm{N}=5.8\right) ; \mathrm{H}_{2} \mathrm{PO}_{4}^{-}-\mathrm{P}=0.6 ; \mathrm{K}^{+}=7.1 ; \mathrm{Ca}^{2+}=$ $0.7 ; \mathrm{Mg}^{2+}=0.3 ; \mathrm{SO}_{4}^{2-}-\mathrm{S}=4.8 ; \mathrm{Cl}=1.4 ; \mathrm{Na}=2.6 ; \mathrm{B}$ $=0.04 ; \mathrm{Cu}=0.04 ; \mathrm{Fe}=2.4 ; \mathrm{Mn}=0.02 ; \mathrm{Zn}=0.03$.

The calculation of the amount of water to be added, through fertigation, was determined by a pilot test using a tray with 160 cone-tainers full of substrate and a container collector installed below. Water was added until there was percolation from the conetainers. As result, $3 \mathrm{~L}$ of nutrient solution were used 
Table 1 - Trade name, manufacturer, iron source, nominal iron percentage declared in the commercial product pack and iron percentage experimentally determined by atomic absorption spectrophotometry.

\begin{tabular}{|c|c|c|c|c|}
\hline Trade name ${ }^{(1)}$ & Manufacturer & Iron source & Declared & Determined \\
\hline & & & \multicolumn{2}{|c|}{ - } \\
\hline GeoFe $11^{\circledR}$ & Rigran & Fe-DTPA & 11 & 13.2 \\
\hline Ultraferro $^{\circledR}$ & TradeCorp & Fe-EDDHA $(4 \% \mathrm{Fe} o, o)$ & 6 & 6.8 \\
\hline Tenso Ferro $^{\circledR}$ & Yara & Fe-EDDHMA $(4.8 \% \mathrm{Fe} o, o)$ & 6 & 7.2 \\
\hline Dissolvine $^{\circledR}$ & Akzo-Nobel & Fe-EDTA & 13 & 14.1 \\
\hline $\mathrm{Fe}\left(\mathrm{NO}_{3}\right)_{3} \cdot 9 \mathrm{H}_{2} \mathrm{O}+$ HEDTA & Merck P.A. & $\mathrm{Fe}^{-H_{E D T A}}{ }^{(2)}$ & 0.92 & 0.92 \\
\hline $\mathrm{FeCl}_{3} \cdot 6 \mathrm{H}_{2} \mathrm{O}$ & ECIBRA P.A. & $\mathrm{FeCl}_{3}$ & 6 & 6.0 \\
\hline $\mathrm{FeSO}_{4} .7 \mathrm{H}_{2} \mathrm{O}$ & Synth P.A. & $\mathrm{FeSO}_{4}$ & 6 & 6.0 \\
\hline $\mathrm{FeSO}_{4} \cdot 7 \mathrm{H}_{2} \mathrm{O}+$ citric acid & Synth P.A. & $\mathrm{FeSO}_{4}+$ citric $\operatorname{acid}^{(3)}$ & 6 & 6.0 \\
\hline
\end{tabular}

(1)Actual analysis of the Fe chelated has not been accomplished. Results only apply to the products used. Different commercial products with the same chelating agent may not present the same behavior; ${ }^{(2)}$ This solution was prepared as follows: a) 8.68 g of HEDTA was dissolved in $\mathrm{NaOH} 1 \mathrm{~mol} \mathrm{~L}^{-1}$ solution; b) $13.31 \mathrm{~g}$ of $\mathrm{Fe}\left(\mathrm{NO}_{3}\right)_{3} .9 \mathrm{H}_{2} \mathrm{O}$ was added to the solution and shacked; c) final $\mathrm{pH}$ was adjusted to 4.0 with $\mathrm{NaOH} 1 \mathrm{~mol} \mathrm{~L}^{-1}$ solution; and d) Final volume was adjusted to $1 \mathrm{~L}$. ${ }^{(3)}$ To each 1 mol of FeSO $.7 \mathrm{H}_{2} \mathrm{O}, 1.1$ mols of citric acid were added (10\% excess citric acid was added to guarantee the complete iron reaction);

per tray with 160 plants, in each fertigation to supply the citrus nutritional demands, resulting an average of $18.75 \mathrm{~mL}$ of nutrient solution per cone-tainer.

The solution, prepared according to Furlani (1998), presented $\mathrm{pH}=6.0, \mathrm{EC}=2.0 \mathrm{dS} \mathrm{m}^{-1}$ and the following chemical composition (in $\mathrm{mg} \mathrm{L}^{-1}$ ): total- $\mathrm{N}=$ $184\left(\mathrm{NO}_{3}{ }^{-}-\mathrm{N}=161\right.$ and $\left.\mathrm{NH}_{4}^{-}-\mathrm{N}=23\right) ; \mathrm{H}_{2} \mathrm{PO}_{4}^{-}-\mathrm{P}=$ 41.6; $\mathrm{K}^{+}=234 ; \mathrm{Ca}^{2+}=103 ; \mathrm{Mg}^{2+}=36 ; \mathrm{SO}_{4}^{2-}-\mathrm{S}^{4}=48$; $\mathrm{B}=0.51 ; \mathrm{Cu}=0.13 ; \mathrm{Mn}=0.64 ; \mathrm{Mo}=0.02$ and $\mathrm{Zn}$ $=0.23$. The iron concentration of the treatments was $1.8 \mathrm{mg} \mathrm{L}^{-1}$, except for the control treatment, prepared without Fe.

Initially concentrated solutions A and B, with macro and micronutrients (except iron) (Furlani, 1998), were used for the preparation of the nutrient solutions. The fertigation was applied five times a week during all the experimental period. At every fertigation, a volume of $120 \mathrm{~L}$ of nutrient solution was prepared, the iron sources being added to the solution individually, at the moment of the fertigation, to avoid precipitation. Through the use of a watering can, the plants were submitted to the different treatments.

Sixty, 90 and 120 days from seed emergency, plant height of 18 plants was measured with a ruler, from the base to the upper apical third. At the end of 120 days, the relative chlorophyll index was measured on 18 plants in the first totally expanded leaf, with a non-destructive analysis, using the SPAD-502 equipment (Minolta Camera Co.).

The assessment to the plant tissue analyses was made at the end of the experiment, at 120 days. The plants were removed from the containers and then divided in apical part (corresponding to five totally expanded leaves plus the related stem), base and roots. After identification samples were dried in a forced air oven at $70^{\circ} \mathrm{C}$, until constant mass for dry matter determination. Samples were then ground in a Wiley type mill and analyzed for total iron concentration, by the dry ash method, according to the analytical procedures described in Bataglia et al. (1983).

The soluble iron extraction method with $\mathrm{HCl}$ was adapted from Takkar \& Kaur (1984). The tissue extract for determination was prepared as follows: 0.1 $\mathrm{g}$ of dry sample was transferred to Erlenmeyer flask and $10 \mathrm{~mL}$ of $\mathrm{HCl} 1 \mathrm{~mol} \mathrm{~L}^{-1}$ were added, shaken at each hour for 24 hours, and subsequently filtered in slow filtrage paper, pre-washed with $\mathrm{HCl} 1 \mathrm{~mol} \mathrm{~L}^{-1}$ solution. The analysis was performed in an atomic absorption spectrometer.

Substrates of all treatments were analyzed according to the Dutch method (1:1.5 substrate:water), adapted from Sonneveld \& Elderen (1994), to evaluate the nutrient status at the end of the experiment.

The number of irrigations made during the experiment and the salt quantities (amendments and iron chelates used) were monitored, in order to obtain the cost of iron sources relative to the total cost of nutrient solution. A price quotation of the different products was made at three different places to compose average values and estimate the fertigation costs, simulating a production of 1,000 seedlings, without considering the other costs inherent to the production.

The experiment was carried out in a completely randomized design arranged in a $9 \times 4$ factorial (eight iron sources + one control and four rootstocks), with four replicates. Each plot was composed of 18 plants. The data of all variables were submitted to analysis of variance, and the means compared at 5\% probability against the clustering test of Scott-Knott in SISVAR statistical computer program. 


\section{RESULTS AND DISCUSSION}

The iron sources provided development differences on the rootstocks. This variability was expected, since the rootstocks presented different genetic characteristics and nutritional requirements, and the iron sources presented differences in chemical composition.

During the experimental period, visual symptoms of iron deficiency were observed in young leaves, on the upper apical third of the plants, allowing the classification of the visual symptoms in a scale, presented in the Table 2, where fertigated plants with salts $\mathrm{FeCl}_{3}, \mathrm{FeSO}_{4}$ and $\mathrm{FeSO}_{4}+$ citric acid, with the chelate Fe-DTPA and control showed the iron deficiency symptoms. The results obtained in the present experiment are in agreement with those obtained by Natt (1992), who reported the Fe-DTPA source as the least efficient in iron supply, with plants usually showing visual iron deficiency symptoms; and also, the results reported by Álvarez-Fernández et al. (1996), who classified the chelates Fe-EDDHA and Fe-EDDHMA as the most efficient iron sources for plant growth, in function of the existence of isomeric orto-orto in composition, larger solubility and maintenance of high amounts of chelated iron in the solution.

Iron treatments provided significant results for plant height and dry matter depending on the citrus rootstock cultivar (Figures 2 and 3). Rangpur lime seedlings from the control treatment presented the smallest dry matter values (a in Figure 2). Similar results were obtained for Cleopatra mandarin seedlings, were the control and Fe-EDTA had the smallest dry matter values, except for the Fe-deficiency visual symptoms, that were not observed in this rootstock cultivar (b in Figure 2; Table 2).
Swingle citrumelo seedlings from Fe-EDTA, $\mathrm{FeSO}_{4}$ and $\mathrm{FeSO}_{4}+$ citric acid treatments had lower plant height and dry matter values in relation to those from the control (a in Figure 3), at 5\% of significance. Poncirus trifoliata seedlings from the Fe-DTPA and Fe-EDTA treatments showed lower plant heights than
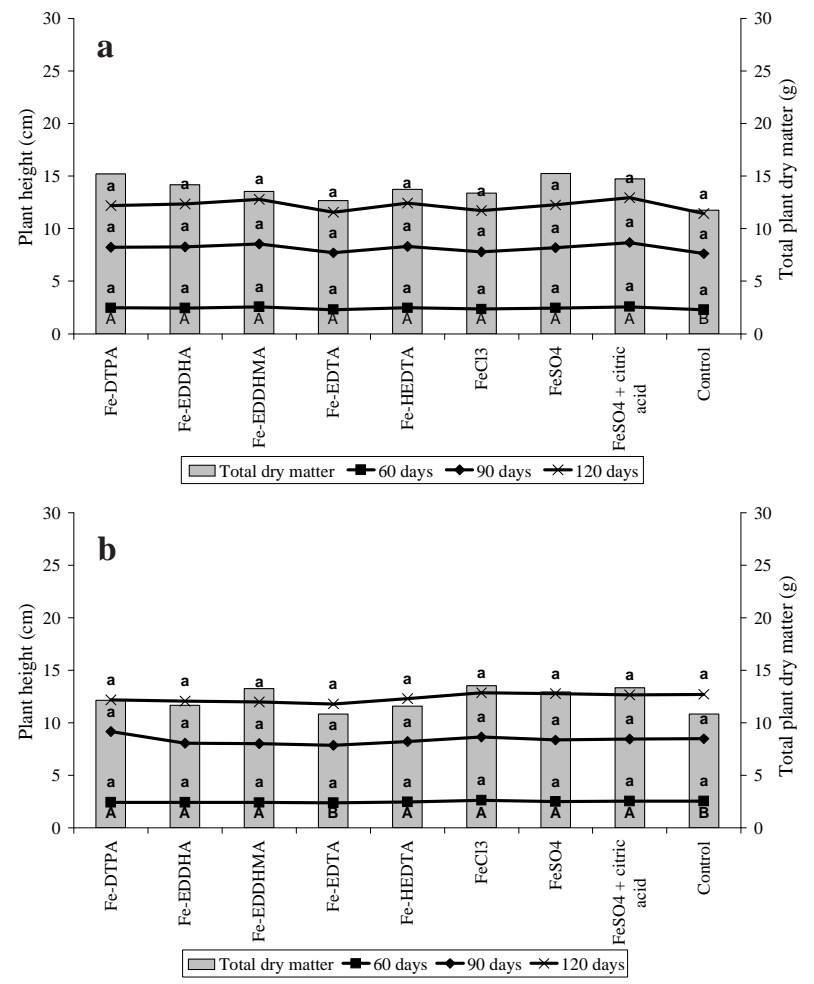

Figure 2 - Rootstock plant height at 60, 90 and 120 days and total dry matter at 120 days grown in $56 \mathrm{~cm}^{3}$ conetainers: (a) Rangpur lime; and (b) Cleopatra mandarin. Average of 18 plants per replicate and 4 replicates. Means followed by the same small letters in plant height and capital letters in total dry matter do not differ (Scott-Knott test, $P>0.05$ ).

Table 2 - Visual determination scale of the symptoms of iron deficiency, in the rootstocks Cleopatra mandarin, Rangpur lime, Swingle citrumelo and Poncirus trifoliata, in cone-tainers of $56 \mathrm{~cm}^{3}$. Average of four replicates.

\begin{tabular}{|c|c|c|c|c|}
\hline \multirow{2}{*}{ Iron source } & \multicolumn{4}{|c|}{ Rootstock $^{(1)}$} \\
\hline & Cleopatra mandarin & Rangpur lime & Swingle citrumelo & Poncirus trifoliata \\
\hline & (1) & Scale of visua & iency symptoms & - \\
\hline Fe-DTPA & - & +++ & ++++ & ++++ \\
\hline Fe-EDDHA & - & ++ & ++ & ++ \\
\hline Fe-EDDHMA & - & + & + & + \\
\hline Fe-EDTA & - & +++ & ++++ & +++++ \\
\hline Fe-HEDTA & - & ++ & +++ & ++++ \\
\hline $\mathrm{FeCl}_{3}$ & - & +++ & ++++ & +++++ \\
\hline $\mathrm{FeSO}_{4}$ & - & +++ & ++++ & +++++ \\
\hline $\mathrm{FeSO}_{4}+$ citric acid & - & +++ & ++++ & +++++ \\
\hline Control & - & +++ & ++++ & +++++ \\
\hline
\end{tabular}


the control, and the ones from Fe-EDTA treatments had also lower dry matter yields $(P<0.05)$ (b in Figure 3). Seedlings treated with $\mathrm{FeCl}_{3}$ presented high plant height and dry matter values, but visual symptoms of Fe-deficiency were observed in these plants (Table 2). Poncirus Trifoliata seedlings from Fe-
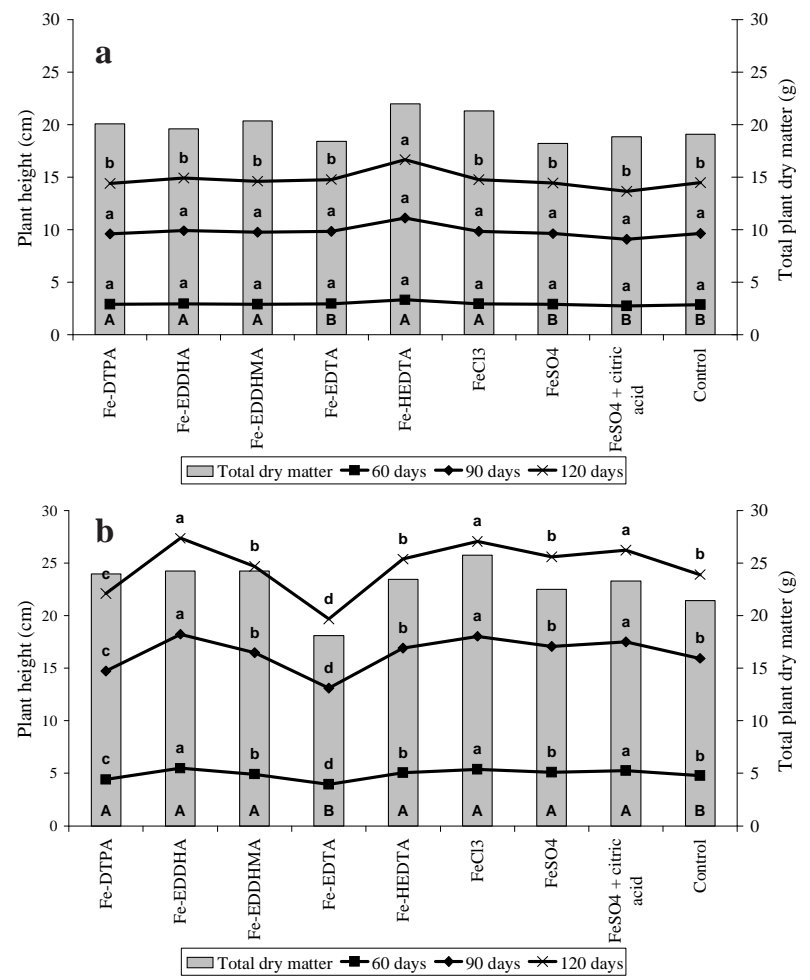

Figure 3 - Rootstock plant height at 60, 90 and 120 days and total dry matter at 120 days grown in $56 \mathrm{~cm}^{3}$ conetainers: (a) Swingle citrumelo and (b) Poncirus trifoliata. Average of 18 plants per replicate and 4 replicates. Means followed by the same small letters in plant height and capital letters in total dry matter do not differ (Scott-Knott test, $P>0.05$ ).
EDDHA and Fe-EDDHMA treatments had similar dry matter yields, but those treated with Fe-EDDHA presented higher values for plant height (b in Figure 3). This is an important characteristic for rootstock seedlings in nurseries, because plant height is the criterion to define the right moment for seedling transplanting and grafting. Thus, seedlings treated with Fe-EDDHA showed to be ready earlier for transplanting that is, in a shorter period of time in the nursery, which is advantageous from the economical point of view, reducing production costs.

According to Pestana et al. (2001) a positive correlation has been found between the SPAD-502 measurements and the leaf total chlorophyll contents $\left(\mu \mathrm{mol} \mathrm{m}{ }^{-2}\right)$. Therefore, the relative chlorophyll index allowed evaluating the plant nutritional status at the end of experiment. In the Fe-EDDHMA and Fe-EDTA treatments, the SPAD-502 readings increased about $23 \%$ and $17 \%$, respectively, for the rootstock Rangpur lime when compared to the control; while the $\mathrm{FeSO}_{4}$ + citric acid treatment increased the readings in $27 \%$ for Swingle citrumelo and 24\% for Poncirus trifoliata (Table 3). These results are similar to the ones obtained by Bañuls et al. (2003), who showed that the iron application frequency partially affected the SPAD-502 readings during the growth period.

In spite of the high Fe concentrations found in the upper apical third of citrus rootstock plants from the control and Fe-EDTA treatments (Table 4), those plants exhibited severe iron deficiency symptoms (Table 2 ), probably because iron was present in the form of non-reactive ferric ion $\left(\mathrm{Fe}^{3+}\right)$, according to Pérez-Sanz \& Lucena (1995), not being easily used in photosynthesis reactions and formation of chlorophyll pigments (Cataldo et al., 1988). Furthermore, Mohammad et al.

Table 3 - Relative chlorophyll index in the upper apical third of citrus plants at 120 days (average of 18 plants per replicate and four replicates).

\begin{tabular}{lccccc}
\hline \multirow{2}{*}{ Iron source } & \multicolumn{5}{c}{ Rootstock } \\
\cline { 2 - 6 } & Cleopatra mandarin & Rangpur lime & Swingle citrumelo & Poncirus trifoliata & Mean \\
\hline Fe-DTPA & $44.6 \mathrm{aA}$ & $37.5 \mathrm{bD}$ & $40.4 \mathrm{bC}$ & $42.1 \mathrm{cB}$ & 41.2 \\
\hline $\mathrm{Fe}-$-EDDHA & $45.6 \mathrm{aA}$ & $38.4 \mathrm{bC}$ & $41.1 \mathrm{bB}$ & $47.4 \mathrm{bA}$ & 43.1 \\
Fe-EDDHMA & $45.7 \mathrm{aA}$ & $41.7 \mathrm{aB}$ & $43.2 \mathrm{bB}$ & $47.0 \mathrm{bA}$ & 44.4 \\
$\mathrm{Fe}-$ EDTA & $45.7 \mathrm{aA}$ & $39.7 \mathrm{aC}$ & $41.9 \mathrm{bB}$ & $43.0 \mathrm{cB}$ & 42.6 \\
$\mathrm{Fe}-\mathrm{HEDTA}$ & $46.6 \mathrm{a}$ & $38.0 \mathrm{bC}$ & $41.0 \mathrm{bB}$ & $47.3 \mathrm{bA}$ & 43.2 \\
$\mathrm{FeCl}_{3}$ & $46.0 \mathrm{aA}$ & $36.5 \mathrm{cC}$ & $40.5 \mathrm{bB}$ & $40.1 \mathrm{~dB}$ & 40.8 \\
$\mathrm{FeSO}_{4}$ & $47.3 \mathrm{aA}$ & $37.4 \mathrm{bC}$ & $37.1 \mathrm{cC}$ & $41.3 \mathrm{~dB}$ & 40.8 \\
$\mathrm{FeSO}_{4}+$ citric acid & $46.6 \mathrm{aB}$ & $34.1 \mathrm{dC}$ & $46.6 \mathrm{aB}$ & $50.3 \mathrm{aA}$ & 44.4 \\
$\mathrm{Control}_{\mathrm{Mean}}$ & $45.3 \mathrm{aA}$ & $33.8 \mathrm{dD}$ & $36.5 \mathrm{cC}$ & $40.5 \mathrm{~dB}$ & 39.0 \\
\hline
\end{tabular}

Mean followed by the same small letters in the columns and capital letters in the lines do not differ (Scott-Knott test, $P>0.05$ ). 
Table 4 - Total iron concentration in the upper apical third of citrus plants, base and roots, at 120 days (average of 18 plants per replicate and four replicates).

\begin{tabular}{|c|c|c|c|c|c|}
\hline \multirow{2}{*}{ Iron source } & \multicolumn{4}{|c|}{ Rootstock } & \multirow{2}{*}{ Mean } \\
\hline & Cleopatra mandarin & Rangpur lime & Swingle citrumelo & Poncirus trifoliata & \\
\hline \multicolumn{6}{|c|}{ - } \\
\hline Fe-DTPA & $61 \mathrm{cB}$ & $95 \mathrm{bA}$ & $77 \mathrm{bA}$ & $64 \mathrm{cB}$ & 74.3 \\
\hline Fe-EDDHA & $45 \mathrm{cB}$ & $70 \mathrm{bA}$ & $60 \mathrm{bA}$ & $42 \mathrm{cB}$ & 53.9 \\
\hline Fe-EDDHMA & $56 \mathrm{cA}$ & $68 \mathrm{bA}$ & $55 \mathrm{bA}$ & $51 \mathrm{cA}$ & 57.3 \\
\hline Fe-EDTA & $115 \mathrm{bA}$ & $95 \mathrm{bA}$ & $89 \mathrm{bA}$ & $89 \mathrm{bA}$ & 97.1 \\
\hline Fe-HEDTA & $57 \mathrm{cB}$ & $80 \mathrm{bA}$ & $67 \mathrm{bA}$ & $52 \mathrm{cB}$ & 63.9 \\
\hline $\mathrm{FeCl}_{3}$ & $55 \mathrm{cA}$ & $70 \mathrm{bA}$ & $66 \mathrm{bA}$ & $48 \mathrm{cA}$ & 59.6 \\
\hline $\mathrm{FeSO}_{4}$ & $97 \mathrm{bA}$ & $76 \mathrm{bB}$ & $69 \mathrm{bB}$ & $65 \mathrm{cB}$ & 76.6 \\
\hline $\mathrm{FeSO}_{4}+$ citric acid & $58 \mathrm{cB}$ & $79 \mathrm{bA}$ & $74 \mathrm{bA}$ & $52 \mathrm{cB}$ & 65.8 \\
\hline Control & $194 \mathrm{aA}$ & $196 \mathrm{aA}$ & $127 \mathrm{aC}$ & $161 \mathrm{aB}$ & 169.2 \\
\hline Mean & 81.9 & 91.9 & 76.0 & 69.1 & \\
\hline \multicolumn{6}{|c|}{ - Base $\left(\mathrm{mg} \mathrm{kg}^{-1}\right)$} \\
\hline Fe-DTPA & $216 \mathrm{bB}$ & 405 aA & $477 \mathrm{aA}$ & $243 \mathrm{cB}$ & 334.9 \\
\hline Fe-EDDHA & $88 \mathrm{cA}$ & $90 \mathrm{cA}$ & 80 eA & $69 \mathrm{dA}$ & 81.4 \\
\hline Fe-EDDHMA & $88 \mathrm{cA}$ & $87 \mathrm{cA}$ & 84 eA & $73 \mathrm{dA}$ & 82.9 \\
\hline Fe-EDTA & $153 \mathrm{bC}$ & $237 \mathrm{bB}$ & $231 \mathrm{~dB}$ & $381 \mathrm{aA}$ & 250.4 \\
\hline Fe-HEDTA & $149 \mathrm{bB}$ & $142 \mathrm{cB}$ & $274 \mathrm{cA}$ & $303 \mathrm{bA}$ & 217.0 \\
\hline $\mathrm{FeCl}_{3}$ & $214 \mathrm{bA}$ & $244 \mathrm{bA}$ & 149 eA & $185 \mathrm{cA}$ & 198.1 \\
\hline $\mathrm{FeSO}_{4}$ & $129 \mathrm{cA}$ & $113 \mathrm{cA}$ & $124 \mathrm{eA}$ & $90 \mathrm{dA}$ & 113.6 \\
\hline $\mathrm{FeSO}_{4}+$ citric acid & 393 aA & 418 aA & $367 \mathrm{bA}$ & $215 \mathrm{cB}$ & 348.2 \\
\hline Control & $168 \mathrm{bA}$ & $107 \mathrm{cA}$ & $123 \mathrm{eA}$ & $107 \mathrm{dA}$ & 126.3 \\
\hline Mean & 177.4 & 204.5 & 212.1 & 185.1 & \\
\hline \multicolumn{6}{|c|}{ - Roots $\left(\mathrm{mg} \mathrm{kg}^{-1}\right)^{(1)}$} \\
\hline Fe-DTPA & 857 aA & $540 \mathrm{aB}$ & $443 \mathrm{aB}$ & $606 \mathrm{aB}$ & 611.4 \\
\hline Fe-EDDHA & $610 \mathrm{bA}$ & 478 aA & 511 aA & 576 aA & 543.8 \\
\hline Fe-EDDHMA & $738 \mathrm{bA}$ & $525 \mathrm{aB}$ & $389 \mathrm{aB}$ & $597 \mathrm{aB}$ & 562.1 \\
\hline Fe-EDTA & 854 aA & $596 \mathrm{aB}$ & $466 \mathrm{aB}$ & $572 \mathrm{aB}$ & 622.0 \\
\hline Fe-HEDTA & $757 \mathrm{bA}$ & 606 aA & $414 \mathrm{aB}$ & 653 aA & 607.2 \\
\hline $\mathrm{FeCl}_{3}$ & 915 aA & $547 \mathrm{aB}$ & $432 \mathrm{aC}$ & $641 \mathrm{aB}$ & 633.7 \\
\hline $\mathrm{FeSO}_{4}$ & 915 aA & $549 \mathrm{aB}$ & $509 \mathrm{aB}$ & $575 \mathrm{aB}$ & 636.9 \\
\hline $\mathrm{FeSO}_{4}+$ citric acid & 833 aA & $558 \mathrm{aB}$ & $430 \mathrm{aB}$ & $480 \mathrm{aB}$ & 575.4 \\
\hline Control & $635 \mathrm{bA}$ & $420 \mathrm{aB}$ & $368 \mathrm{aB}$ & 733 aA & 539.0 \\
\hline Mean & 790.4 & 535.5 & 440.0 & 603.6 & \\
\hline
\end{tabular}

${ }^{(1)}$ Analysis of variance of original data transformed to $\sqrt{x}$. Means followed by the same small letters in the columns and capital letters in the lines, do not differ (Scott-Knott test, $P>0.05$ ).

(1998) observed that the total iron concentration was always higher in chlorotic leaves as compared to green leaves and was not related to the chlorosis degree.

The application of Fe-EDTA increased young plant leaf iron concentrations in $10 \%$ when compared to three-year-old plants treated with and without iron chelates (Natt, 1992). However, opposite results were obtained in this experiment, where plants treated with Fe-EDTA showed severe visual chlorosis symptoms of iron deficiency, despite the high total iron concentration found in them (Table 4). On the other hand, in this experiment, no significant differences were found between Fe-EDDHA and Fe-EDDHA chelate treatments (Table 4) and these results are in agreement with the ones obtained by Lucena et al. (1992). According to these authors, there is large variability among chelates with the same chelating agent, but different formulations. 
It is difficult to identify iron deficiency based on plant total $\mathrm{Fe}$ concentration, because leaves exhibiting visual symptoms of iron deficiency may present considerably high total iron concentrations (the so-called iron deficiency "paradox", according to El-Baz et al., 1998). The determination of active iron was suggested by Pierson \& Clark (1984), that proposed an adapted procedure to determine this iron fraction in plants.

Therefore, in this experiment, once plants treated with Fe-EDTA showed severe visual chlorosis symptoms of Fe-deficiency, despite their high total Feconcentration (Table 4), an attempt was made to determine the leaf soluble iron (with $\mathrm{HCl} 1 \mathrm{~mol} \mathrm{~L}^{-1}$, according to El-Baz et al., 1998) to observe how much of the total iron was available to the photosynthetic reactions and pigment synthesis. Lang et al. (1990) ob- served that the iron extraction in fresh leaves with $\mathrm{HCl}$ $1 \mathrm{~mol} \mathrm{~L}^{-1}$ was a good indicator of the iron status in plants at flowering. Also, Ohwaki \& Sugahara (1993) reported that the genotypic differences among Fe-deficient chickpea sensitive and resistant cultivars were attributed to the active iron in leaves grown under iron stress conditions.

The results on leaf soluble iron concentration showed no significant interactions between iron sources and rootstocks (Table 5). However, plants from control and Fe-EDTA treatment presented the highest values, and the soluble iron concentration determined tended to decrease with the increasing chlorosis degree.

The percentage of soluble iron in relation to the total-Fe was found to be closely related to the chlorosis degree (Table 5 and 6). Plants from the control pre-

Table 5 - Soluble iron (in $\mathrm{HCl} 1 \mathrm{~mol} \mathrm{~L}^{-1}$ ) concentration in the upper apical third of citrus plants at 120 days (average of 18 plants per replicate and four replicates).

\begin{tabular}{lccccc}
\hline \multirow{2}{*}{ Iron source } & \multicolumn{4}{c}{ Rootstock } & \multirow{2}{*}{ Mean } \\
\cline { 2 - 4 } & Cleopatra mandarin & Rangpur lime & Swingle citrumelo & Poncirus trifoliata & \\
\hline & 38.2 & 57.2 & 45.0 & 37.5 & $44.5 \mathrm{c}$ \\
\hline Fe-DTPA & 25.0 & 44.0 & 37.5 & 27.2 & $33.4 \mathrm{c}$ \\
Fe-EDDHA & 36.2 & 49.0 & 34.7 & 37.5 & $39.3 \mathrm{c}$ \\
\hline Fe-EDDHMA & 85.5 & 70.0 & 54.0 & 60.0 & $67.3 \mathrm{a}$ \\
$\mathrm{Fe}-$ EDTA & 41.7 & 64.3 & 48.0 & 35.7 & $47.4 \mathrm{c}$ \\
\hline $\mathrm{Fe}-\mathrm{HEDTA}$ & 35.7 & 55.5 & 50.2 & 31.7 & $43.3 \mathrm{c}$ \\
$\mathrm{FeCl}_{3}$ & 74.5 & 60.7 & 43.2 & 40.2 & $54.6 \mathrm{~b}$ \\
$\mathrm{FeSO}_{4}$ & 41.5 & 55.7 & 57.0 & 34.0 & $47.0 \mathrm{c}$ \\
$\mathrm{FeSO}_{4}+$ citric acid & 88.5 & 76.0 & 47.0 & 64.5 & $69.0 \mathrm{a}$ \\
$\mathrm{Control}$ & 51.8 & 59.1 & 46.3 & 40.9 & \\
\hline Mean & & &
\end{tabular}

Mean followed by the same small letters in the columns and capital letters in the lines, do not differ (Scott-Knott test, $P>0.05$ ).

Table 6 - Percentage of soluble iron (in $\mathrm{HCl} 1 \mathrm{~mol} \mathrm{~L}^{-1}$ ) in relation to the total iron concentration in the upper apical third of citrus plants at 120 days (average of 18 plants per replicate and four replicates).

\begin{tabular}{lccccc}
\hline \multirow{2}{*}{ Iron source } & \multicolumn{4}{c}{ Rootstock } & \multirow{2}{*}{ Mean } \\
\cline { 2 - 4 } & Cleopatra mandarin & Rangpur lime & Swingle citrumelo & Poncirus trifoliata & \\
\hline Fe-DTPA & 63.2 & 60.6 & 59.2 & 62.2 & $61.3 \mathrm{~b}$ \\
\hline Fe-EDDHA & 57.6 & 63.7 & 63.7 & 68.5 & $63.4 \mathrm{~b}$ \\
\hline Fe-EDDHMA & 65.1 & 72.0 & 63.2 & 74.2 & $68.6 \mathrm{a}$ \\
\hline $\mathrm{Fe}-E D T A$ & 74.9 & 73.8 & 59.3 & 68.9 & $69.2 \mathrm{a}$ \\
\hline $\mathrm{Fe}-\mathrm{HEDTA}$ & 72.8 & 81.1 & 71.3 & 69.1 & $73.6 \mathrm{a}$ \\
$\mathrm{FeCl}_{3}$ & 64.5 & 78.8 & 76.6 & 64.7 & $71.1 \mathrm{a}$ \\
$\mathrm{FeSO}_{4}$ & 76.5 & 79.8 & 63.7 & 62.6 & $70.6 \mathrm{a}$ \\
$\mathrm{FeSO}_{4}+$ citric acid & 72.1 & 68.8 & 76.8 & 64.9 & $70.6 \mathrm{a}$ \\
$\mathrm{Control}$ & 46.2 & 42.8 & 43.8 & 41.3 & $43.5 \mathrm{c}$ \\
\hline Mean & 65.9 & 69.0 & 64.2 & 64.1 & \\
\hline
\end{tabular}

Mean followed by the same small letters in the columns and capital letters in the lines, do not differ (Scott-Knott test, $P>0.05$ ). 
sented the lowest percentages of soluble-Fe in relation to total iron (Table 6), which may explain their typical chlorosis symptoms of iron deficiency (Table 2). The authors could not found a physiological explanation for the high Fe levels found in plants treated with FeEDTA, and of the occurrence of visual iron deficiency symptoms in the plants of that treatment. Though, some studies indicate that uptake of hydrophilic solutes such as metal-EDTA complexes is believed to oc- cur via bypass apoplastic flow, into the plant (Schaider et al., 2006; Epstein et al., 1999). These are open questions that will need further research to be clarified.

When comparing the tissue Fe-concentration among different plant parts, no significant interactions among iron sources and rootstocks were observed (Table 7). In the Fe-EDTA and control treatments, differences among Fe-concentrations of upper apical third of citrus rootstock plants were found (Table 7). In the

Table 7 - Iron accumulation in the upper apical third, base and roots of citrus plants at 120 days (average of 18 plants per replicate and four replicates).

\begin{tabular}{|c|c|c|c|c|c|}
\hline \multirow{2}{*}{ Iron source } & \multicolumn{4}{|c|}{ Rootstock } & \multirow{2}{*}{ Mean } \\
\hline & Cleopatra mandarin & Rangpur lime & Swingle citrumelo & Poncirus trifoliata & \\
\hline \multicolumn{6}{|c|}{ - Uper apical third $\left(\mu \text { glant }^{-1}\right)^{(1)}$} \\
\hline Fe-DTPA & 10 & 20 & 15 & 10 & $13.8 \mathrm{~b}$ \\
\hline Fe-EDDHA & 7 & 12 & 7 & 5 & $7.8 \mathrm{~b}$ \\
\hline Fe-EDDHMA & 7 & 10 & 10 & 7 & $8.5 \mathrm{~b}$ \\
\hline Fe-EDTA & 12 & 17 & 27 & 22 & $19.5 \mathrm{a}$ \\
\hline Fe-HEDTA & 10 & 22 & 10 & 10 & $13.0 \mathrm{~b}$ \\
\hline $\mathrm{FeCl}_{3}$ & 10 & 12 & 12 & 7 & $10.3 \mathrm{~b}$ \\
\hline $\mathrm{FeSO}_{4}$ & 15 & 12 & 10 & 10 & $11.8 \mathrm{~b}$ \\
\hline $\mathrm{FeSO}_{4}+$ citric acid & 10 & 15 & 17 & 7 & $12.3 \mathrm{~b}$ \\
\hline Control & 22 & 35 & 20 & 32 & $27.3 \mathrm{a}$ \\
\hline Mean & $11.4 \mathrm{~A}$ & $17.2 \mathrm{~A}$ & $14.2 \mathrm{~A}$ & $12.2 \mathrm{~A}$ & \\
\hline \multicolumn{6}{|c|}{ ( $\left.\mathrm{g}_{\mathrm{plant}}{ }^{1}\right)^{(1)}$} \\
\hline Fe-DTPA & 72 & 157 & 260 & 207 & $174.0 \mathrm{a}$ \\
\hline Fe-EDDHA & 32 & 37 & 45 & 60 & $43.5 \mathrm{~d}$ \\
\hline Fe-EDDHMA & 35 & 35 & 50 & 55 & $43.8 \mathrm{~d}$ \\
\hline Fe-EDTA & 67 & 72 & 155 & 192 & $121.5 \mathrm{~b}$ \\
\hline Fe-HEDTA & 70 & 65 & 170 & 190 & $123.8 \mathrm{~b}$ \\
\hline $\mathrm{FeCl}_{3}$ & 80 & 77 & 85 & 145 & $96.8 \mathrm{c}$ \\
\hline $\mathrm{FeSO}_{4}$ & 50 & 40 & 62 & 62 & $53.5 \mathrm{~d}$ \\
\hline $\mathrm{FeSO}_{4}+$ citric acid & 150 & 162 & 197 & 172 & $170.3 \mathrm{a}$ \\
\hline Control & 72 & 20 & 32 & 67 & $47.8 \mathrm{~d}$ \\
\hline Mean & $69.8 \mathrm{~B}$ & $73.9 \mathrm{~B}$ & $117.3 \mathrm{~A}$ & $127.8 \mathrm{~A}$ & \\
\hline \multicolumn{6}{|c|}{ Roots $\left(\mu \text { g plant }^{-1}\right)^{(1)}$} \\
\hline Fe-DTPA & 152 & 155 & 175 & 275 & $189.3 \mathrm{a}$ \\
\hline Fe-EDDHA & 92 & 102 & 172 & 230 & $149.0 \mathrm{~b}$ \\
\hline Fe-EDDHMA & 155 & 130 & 150 & 275 & $177.5 \mathrm{a}$ \\
\hline Fe-EDTA & 122 & 110 & 157 & 207 & $149.0 \mathrm{~b}$ \\
\hline Fe-HEDTA & 120 & 135 & 145 & 255 & $163.8 \mathrm{~b}$ \\
\hline $\mathrm{FeCl}_{3}$ & 207 & 140 & 187 & 315 & $212.3 \mathrm{a}$ \\
\hline $\mathrm{FeSO}_{4}$ & 172 & 182 & 165 & 222 & $185.3 \mathrm{a}$ \\
\hline $\mathrm{FeSO}_{4}+$ citric acid & 195 & 145 & 187 & 215 & $185.5 \mathrm{a}$ \\
\hline Control & 95 & 75 & 127 & 270 & $141.8 \mathrm{~b}$ \\
\hline Mean & $145.6 \mathrm{~B}$ & $130.4 \mathrm{~B}$ & $162.8 \mathrm{~B}$ & $251.6 \mathrm{~A}$ & \\
\hline
\end{tabular}

${ }^{(1)}$ Analysis of variance of original data transformed to $\sqrt{x}$. Means followed by the same small letters in the columns and capital letters in the lines do not differ (Scott-Knott test, $P>0.05$ ). 
basal part of Swingle citrumelo and Poncirus trifoliata plants of Fe-DTPA and $\mathrm{FeSO}_{4}+$ citric acid treatments higher iron concentrations were found as compared to the other plants. Root Fe-concentrations in plants of Poncirus trifoliata were higher than in the roots of the other rootstocks (Table 7).

Tables 8 and 9 show pH values, EC, macro and micronutrient concentrations in the substrate, at end of experiment. However, there was not significance in the Scott-Knott test $(P<0.05)$.

Among the aspects involved in the complex system of seedling production and commercialization, the economical one is the most important and it will influence the choice of products and management procedures that assure quality and minimize production costs. Aiming to contribute in this aspect, the price of the products used were quoted at the experiment date, and the economical analysis (Table 10) showed the following decreasing cost values of iron sources in relation to the nutrient solution total costs: FeHEDTA $(37.25 \%)>\mathrm{FeCl}_{3}(4.61 \%)>$ Fe-EDDHMA $(4.53 \%)>$ Fe-EDDHA $(3.35 \%)>$ Fe-DTPA $(2.91 \%)$ $>$ Fe-EDTA $(1.08 \%)>\mathrm{FeSO}_{4}+$ citric acid $(0.78 \%)>$ $\mathrm{FeSO}_{4}(0.25 \%)$.

The Fe-HEDTA was the most expensive iron chelate, corresponding to $37.25 \%$ of the nutrient so-

Table 8 - pH values, CE and macronutrient concentrations in the substrate, at end of experiment, of the rootstocks Cleopatra mandarin, Rangpur lime, Swingle citrumelo and Poncirus trifoliata, in cone-tainers of $56 \mathrm{~cm}^{3}$. Average of four replicates.

\begin{tabular}{|c|c|c|c|c|c|c|c|c|c|}
\hline Iron source & $\mathrm{pH}$ & $\mathrm{EC}$ & $\mathrm{N}-\mathrm{NO}_{3}$ & $\mathrm{~N}-\mathrm{NH}_{4}$ & $\mathrm{P}$ & $\mathrm{K}$ & $\mathrm{Ca}$ & $\mathrm{Mg}$ & $\mathrm{S}$ \\
\hline & & $\mathrm{dS} \mathrm{m}^{-1}$ & $\ldots \ldots$ & - & -...- & $m g \mathrm{~L}^{-1}$ & 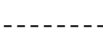 & (n..... & (n) \\
\hline Fe-DTPA & 5.5 & 1.5 & 27.4 & 2.0 & 3.7 & 64.6 & 10.2 & 8.4 & 21.2 \\
\hline Fe-EDDHA & 5.3 & 1.5 & 28.8 & 2.3 & 3.3 & 61.8 & 11.7 & 10.0 & 22.8 \\
\hline Fe-EDDHMA & 5.4 & 1.5 & 23.1 & 2.2 & 3.8 & 53.3 & 9.5 & 7.2 & 19.0 \\
\hline Fe-EDTA & 5.4 & 1.6 & 31.2 & 2.3 & 3.7 & 62.7 & 9.7 & 7.8 & 20.2 \\
\hline Fe-HEDTA & 5.6 & 1.5 & 25.1 & 2.1 & 3.6 & 48.6 & 10.0 & 7.7 & 18.7 \\
\hline $\mathrm{FeCl}_{3}$ & 5.4 & 1.5 & 23.2 & 2.0 & 3.8 & 53.7 & 7.9 & 6.4 & 18.6 \\
\hline $\mathrm{FeSO}_{4}$ & 5.4 & 1.5 & 27.5 & 2.3 & 3.6 & 56.4 & 10.8 & 9.3 & 20.8 \\
\hline $\mathrm{FeSO}_{4}+$ citric acid & 5.3 & 1.5 & 29.6 & 1.6 & 3.3 & 56.4 & 11.7 & 10.6 & 23.3 \\
\hline Control & 5.4 & 1.5 & 25.6 & 1.8 & 3.1 & 55.2 & 10.1 & 8.8 & 21.3 \\
\hline Mean & 5.4 & 1.5 & 26.8 & 2.1 & 3.6 & 56.9 & 10.2 & 8.5 & 20.7 \\
\hline C.V. $(\%)=$ & 2.81 & 20.76 & 29.72 & 12.75 & 11.96 & 13.98 & 16.35 & 19.80 & 6.93 \\
\hline$P>\mathrm{F}$ & n.s. & n.s. & n.s. & n.s. & n.s. & n.s. & n.s. & n.s. & n.s. \\
\hline
\end{tabular}

n.s. No significant (Scott-Knott test, $P>0.05$ ).

Table 9 - Micronutrient concentrations in the substrate, at end of experiment, of the rootstocks Cleopatra mandarin, Rangpur lime, Swingle citrumelo and Poncirus trifoliata, in cone-tainers of $56 \mathrm{~cm}^{3}$. Average of four replicates.

\begin{tabular}{lccccc}
\hline Iron source & $\mathrm{B}$ & $\mathrm{Cu}$ & $\mathrm{Fe}$ & $\mathrm{Mn}$ & $\mathrm{Zn}$ \\
\hline & 0.17 & 0.06 & 1.00 & 0.06 & 0.04 \\
Fe-DTPA & 0.16 & 0.05 & 0.98 & 0.06 & 0.04 \\
$\mathrm{Fe}-$ EDDHA & 0.15 & 0.04 & 1.05 & 0.05 & 0.03 \\
Fe-EDDHMA & 0.17 & 0.05 & 0.92 & 0.05 & 0.04 \\
$\mathrm{Fe}-$ EDTA & 0.16 & 0.06 & 0.92 & 0.06 & 0.04 \\
$\mathrm{Fe}-\mathrm{HEDTA}$ & 0.16 & 0.06 & 1.06 & 0.05 & 0.04 \\
$\mathrm{FeCl}_{3}$ & 0.17 & 0.04 & 0.95 & 0.06 & 0.03 \\
$\mathrm{FeSO}_{4}$ & 0.16 & 0.05 & 0.86 & 0.08 & 0.03 \\
$\mathrm{FeSO}_{4}+$ citric acid & 0.16 & 0.05 & 0.84 & 0.06 & 0.03 \\
$\mathrm{Control}_{\mathrm{Mean}}$ & 0.16 & 0.05 & 0.95 & 0.06 & 0.04 \\
$\mathrm{C} . \mathrm{V} .(\%)=$ & 7.93 & 17.06 & 18.03 & 36.68 & 16.93 \\
$P>\mathrm{F}$ & n.s. & n.s. & n.s. & n.s. & n.s. \\
\hline
\end{tabular}

n.s. No significant (Scott-Knott test, $P>0.05$ ). 
Table 10 - Cost and percentile participation of salts and chelates in the nutrient solution total cost for the production of 1,000 citrus seedlings.

\begin{tabular}{lccc}
\hline Chelate and salt & \multicolumn{2}{c}{ Cost } & $\begin{array}{c}\text { Cost proportion of iron sources in the nutrient } \\
\text { solution total cost }{ }^{(2)}\end{array}$ \\
\hline Fe-DTPA & $\mathrm{R} \$$ & $\mathrm{US} \$^{(1)}$ & $\%$ \\
Fe-EDDHA & 0.14 & 0.06 & 2.91 \\
Fe-EDDHMA & 0.16 & 0.07 & 3.35 \\
$\mathrm{Fe}-E D T A$ & 0.22 & 0.10 & 4.53 \\
$\mathrm{Fe}-\mathrm{HEDTA}$ & 0.05 & 0.02 & 1.08 \\
$\mathrm{FeCl}_{3}$ & 1.80 & 0.79 & 37.25 \\
$\mathrm{FeSO}_{4}$ & 0.22 & 0.10 & 4.61 \\
$\mathrm{FeSO}_{4}+$ citric acid & 0.01 & 0.01 & 0.25 \\
\hline $\mathrm{CO}_{4}$ & 0.04 & 0.02 & 0.78 \\
\hline
\end{tabular}

${ }^{(1)}$ Comercial US dolar in Brazil in 12/12/2005 = R \$ 2.26. ${ }^{\left({ }^{2}\right)}$ Total cost of nutrient solution = R \$ 4.83 (US\$ 2.13).

lution total costs, because of the price of $\mathrm{Fe}\left(\mathrm{NO}_{3}\right)_{3} \cdot 9 \mathrm{H}_{2} \mathrm{O}$ used in this chelate composition, a fact that restricts its use for commercial production of citrus seedlings. Besides, plants treated with FeHEDTA presented visual symptoms of Fe-deficiency. The salt $\mathrm{FeCl}_{3}$ also presented relatively high percent cost in the solution due to the original material high price. In sequence to the cost classification, the iron chelates Fe-EDDHMA and Fe-EDDHA, although slightly more expensive than the Fe-DTPA, Fe-EDTA, $\mathrm{FeSO}_{4}+$ citric acid and $\mathrm{FeSO}_{4}$ sources, represent an advantage in their use, due to the benefits they provided in the correction of iron deficiencies. The FeEDTA and $\mathrm{FeSO}_{4}$ should be only used as alternative sources to reduce even more the costs, but they are not as effective as Fe-EDDHMA and Fe-EDDHA, since plants treated with Fe-EDTA and $\mathrm{FeSO}_{4}$ presented Fe-deficiency symptoms, at the same iron rates.

\section{CONCLUSIONS}

The efficiency of iron sources in preventing iron deficiency in citrus rootstock cultivar development, cultivated on pine/bark vermiculite mixed substrate, was initially estimated through visual symptoms, and their efficacy followed the order: Control $=\mathrm{FeCl}_{3}$ $=\mathrm{FeSO}_{4}=\mathrm{FeSO}_{4}+$ citric acid $=$ Fe-EDTA $<$ Fe-DTPA $<$ Fe-HEDTA $<$ Fe-EDDHA $<$ Fe-EDDHMA. Also through visual symptoms, different rootstock cultivar degrees of iron deficiency were found, which followed the order: Poncirus trifoliata > Swingle Citrumelo > Rangpur lime > Cleopatra mandarin.

The relative chlorophyll index (SPAD), the total iron concentration and the soluble iron concentration (in $\mathrm{HCl} 1 \mathrm{~mol} \mathrm{~L}^{-1}$ ) were not good indicators to diagnose the effect of the different sources of iron in the rootstocks.
Plants treated with Fe-EDDHA did not show any visual symptoms of iron deficiency and this chelate provided better quality seedlings (higher plants), being therefore, recommended for citrus seedling production in nurseries, presenting acceptable cost in relation to the total cost of the nutrient solution. The chelate Fe-EDDHMA presented similar results, but with a slightly higher cost as compared to FeEDDHA.

The rootstock Cleopatra mandarin do not show differences in relation to the sources of iron, being able to be grown with the use of salts in hydroponic like cultures, which are of lower costest than the chelates.

\section{ACKNOWLEDGMENTS}

To Citrograf and Sucocitrico Cutrale for the citrus rootstock seedlings; to Eucatex for the substrate; and Tradecorp, Rigran and Yara enterprises for some iron sources. Thanks to Dr José Guilherme de Freitas, Dr Mônica Ferreira de Abreu and M.Sc. Átila B. B. Cardinal of Instituto Agronômico (IAC) for laboratory support.

\section{REFERENCES}

AHRLAND, S.; DAHLGREN Å.; PERSSON, I. Stabilities and hydrolysis of some iron(III) and manganese(III) complexes with chelating ligands. Acta Agriculturae Scandinavica, v.40, p.101-111, 1990.

ALBANO, J.; MILLER, W.B. Light degrades iron-chelates in fertilizer solutions, affecting physiology of iron acquisition in Marigold (Tagetes erecta L.). In: SOUTHERN NURSERYMEN'S ASSOCIATION RESEARCH CONFERENCE, 40, Marietta, GA, 1995. Proceedings. McMinnville, TN: SNA, 1995. p.18-20. Available at: http://www.clemson.edu/hort/sctop/bsec/bsec04.php. Accessed 23 Nov. 232005.

ÁLVAREZ-FERNÁNDEZ, A.; GÁRATE, A.; JUÁREZ, M.; LUCENA, J.J. Tomato acquisition of iron from chelates in calcareous sandy substrate. Journal of Plant Nutrition, v.19, p.1279-1293, 1996. 
BAÑULS, J.; QUIÑONES, A.; MARTÍN, B.; PRIMO-MILLO, E.; LEGAZ, F. Effects of the frequency of iron chelate supply by fertigation on iron chlorosis in citrus. Journal of Plant Nutrition, v.26, p.1985-1996, 2003.

BATAGLIA, O.C.; FURLANI, A.M.C.; TEIXEIRA, J.P.F.; FURLANI, P.R.; GALLO, J.R. Métodos de análise química de plantas. Campinas: Instituto Agronômico, 1983. 43p. (Boletim Técnico, 78).

BERMÚDEZ, D.; JUÁREZ, M.; JORDÁ, J.D.; SÁNCHEZANDREU, J.J.; LUCENA, J.J.; SÁNCHEZ-SÁNCHEZ, A. Effect of $\mathrm{pH}$ on the stability of the chelates FeEDDHA, FeEDDHMA and their isomers. Agrochimica, v.46, p.202-211, 2002.

BIENFAIT, H.F. Regulated redox processes at the plasmalemma of plant root cells and their function in iron uptake. Journal of Bioenergetics and Biomembranes, v.17, p.73-83, 1985.

CATALDO, D.A.; MCFADDEN, K.M.; GARLAND, T.R.; WILDUNG, R.E. Organic constituents and complexation of nickel (II), iron (III), cadmium (II) and plutonium (IV) in soybean xylem exudates. Plant Physiology, v.86, p.734-739, 1988.

EL-BAZ, F.K.; EL-MOBDE, E.A.; ZENAIB, A.; AMAL, A.M. Determination of $\mathrm{Fe}^{+2}$ and soluble zinc as biochemical indicators for the diagnosis of iron and zinc deficiency in snap bean (Phaseolus vulgaris) and faba bean (Vicia faba) plants. Egyptian Journal of Physiological Sciences, v.22, p.25-39, 1998.

EPSTEIN, A.L.; GUSSMAN, C.D.; BLAYLOCK, M.J.; YERMIYAHU, U.; HUANG, J.W.; KAPULNIK, Y.; ORSER, C.S. EDTA and Pb-EDTA accumulation in Brassica juncea grown in Pb-amended soil. Plant and Soil, v.208, p.87-94, 1999.

FERRAREZI, R.S. Fontes de ferro no desenvolvimento de portaenxertos cítricos produzidos em substrato. Campinas: Instituto Agronômico/IAC, 2006. 102p. (Dissertação - Mestrado em Agricultura Tropical e Subtropical). Available at: http:// www.iac.sp.gov.br/PosIAC/Rhuanito2006.pdf. Accessed 22 May 2007.

FURLANI, P.R. Instruções para o cultivo de hortaliças de folhas pela técnica da hidroponia - NFT. Campinas: Instituto Agronômico, 1998. 30p. (Boletim Técnico, 168).

GÁRATE, A.; LUCENA, J.J. Eficácia de quelatos de Fe em um sistema de riego por goteo. Suelo y Planta, v.1, p.439-451, 1991.

GARCÍA-MARCO, S.; MARTÍNEZ, N.; YUNTA, F.; HERNÁNDEZ-APAOLAZA, L.; LUCENA, J.J. Effectiveness of ethylenediamine- $N$ (o-hydroxyphenylacetic)- $N$ ' $(p$ hydroxyphenylacetic) acid (o,p-EDDHA) to supply iron to plants. Plant and Soil, v.279, p.31-40, 2006.

LANG, H.J.; ROSENFIELD, C.L.; REED, D.W. Response of Ficus benjamina and Dracaena marginata to iron stress. Journal of the American Society for Horticultural Science, v.115, p.589-592, 1990.

LUCENA, J.J. Fe chelates for remediation of Fe chlorosis in Strategy I plants. Journal of Plant Nutrition, v.26, p.1969-1984, 2003.

LUCENA, J.J.; MANZANARES, M.; GÁRATE, A. Comparative study of the efficacy of commercial Fe-chelates using a new test. Journal of Plant Nutrition, v.15, p.1995-2006, 1992.

MOHAMMAD, M.J.; HUSAM, N.; KHRESAT, S. Nitric acid- and o-phenanthroline-extractable iron for diagnosis of iron chlorosis in citrus lemon trees. Communications in Soil Science and Plant Analysis, v.29, p.1035-1043, 1998.
NATT, C. Effect of slow release iron fertilizers on chlorosis in grape. Journal of Plant Nutrition, v.15, p.1891-1912, 1992.

NORVELL, W.A. Equilibria of metal chelates in soil solution. In: MORTVEDT, J.J.; GIORDANO, P.M.; LINDSAY, W.L. Micronutrients in agriculture. 1.ed. Madison, WI: SSSA, 1972. p.549-592.

OHWAKI, Y.; SUGAHARA, K. Genotypical differences in responses to iron deficiency between sensitive and resistant cultivars of chickpea (Cicer arietinum). Plant and Soil, v.155/156, p.473476, 1993.

PÉREZ-SANZ, A.; LUCENA, J.J. Synthetic iron oxides as sources of Fe in a hydroponic culture of sunflower. In: ABADIA, J. Iron nutrition in soils and plants. Dordrecht: Kluwer Academic, 1995. p.241-246.

PESTANA, M.; DAVID, M.; DE-VARENNES, A.; ABADIA, J.; FARIA, E.A. Responses of "Newhall" orange trees to iron deficiency in hydroponics: effects on leaf chlorophyll, photosynthetic efficiency, and root ferric chelate reductase activity. Journal of Plant Nutrition, v.24, p.1609-1620, 2001.

PIERSON, E.E.; CLARK, R.R. Ferrous iron determination in plant tissue. Journal of Plant Nutrition, v.7, p.107-110, 1984.

RÖMHELD, V. Aspectos fisiológicos dos sintomas de deficiência e toxicidade de micronutrientes e elementos tóxicos em plantas superiores. In: FERREIRA, M.E.; CRUZ, M.C.P.; RAIJ, B. van; ABREU, C.A. Micronutrientes e elementos tóxicos na agricultura. Jaboticabal: CNPq/FAPESP/POTAFOS, 2001. p.71-86.

SÁNCHEZ-ANDREU, J.; JORDA, J.; JUAREZ, M. Reactions of Fe-EDTA and Fe-EDDHA applied to calcareous soils. In: CHEN, Y.; HADAR, Y. Iron nutrition and interaction in plants. Dordrecht: Kluwer Academic, 1991. p.57-62.

SCHAIDER, L.A.; PARKER, D.R.; SEDLAK, D.L. Uptake of EDTA-complexed $\mathrm{Pb}, \mathrm{Cd}$ and Fe by solution and sand-cultured Brassica juncea. Plant and Soil, v.286, p.377-391, 2006.

SONNEVELD, C.; ELDEREN, C.W. van. Chemical analysis of peaty growing media by means of water extraction. Communications in Soil Science and Plant Analysis, v.25, p.3199-3208, 1994.

TAKKAR, P.N.; KAUR, N.P. HCl method for $\mathrm{Fe}^{+2}$ estimation to resolve iron chlorosis in plants. Journal of Plant Nutrition, v.7, p.1-5, 1984.

YUNTA, F.; SIERRA, M.A.; GÓMEZ-GALLEGO, M.; ALCAZÁR, R.; GARCÍA-MARCO, S.; LUCENA, J.J. Methodology to screen new iron chelates: prediction of their behavior in nutrient solution and soil conditions. Journal of Plant Nutrition, v.26, p.1955-1968, 2003a.

YUNTA, F.; SIERRA, M.A.; GARCÍA-MARCO, S.; LUCENA, J.J. Theoretical speciation of ethylenediamine- $N-(o-$ hydroxyphenylacetic)-N'-(p-hydroxyphenylacetic) acid (o,pEDDHA) in agronomic conditions. Journal of Agricultural and Food Chemistry, v.51, p.5391-5399, 2003b.

Received February 06, 2006

Accepted July 05, 2007 